\title{
THEORETICAL STUDY RESULTS OF PRODUCT FLOW MANAGEMENT PROCESS IN HAMMER-TYPE SHREDDER WORKING CHAMBER
}

\author{
Yuriy Ushakov, Vladimir Shakhov, Evgeniy Asmankin, Denis Naumov \\ Orenburg State Agrarian University, Russia \\ 1u6j1a159@mail.ru, shahov-v@yandex.ru,1u6j1a159asmankin@mail.ru, naumov3091@mail.ru
}

\begin{abstract}
The problem under study is the uneven grinding and high specific energy consumption of grain crop hammer-type shredders with centrifugal segregation units of the air-product flow inside the working chamber. Elimination of negative consequences of segregation during grinding of the grain mass is achieved by improving the efficiency of the air-product flow management inside the hammer-type shredder working chamber; by separating of standard particles from the main flow and their lateralization (withdrawing to lateral areas) to remove from the working chamber. The analytical dependences of the trajectories of the air-product layer particles during the motion from the reflector to the sieve and their velocities profile have been obtained. The optimal range of tilt angles of the reflecting surface of the separator is in the range from 40 degrees to 50 degrees. From the condition of uniform distribution of particles on the surface of the sieve, the equation of its shape for this range has been obtained. The method of changing the shape of the reflecting surface of the separator for the use of a plane-shaped sieve is proposed. Analytical dependences allow, depending on the shape of the separator, to set the shape of the sieve and vice versa - depending on the shape of the sieve to set the shape of the separator. At the same time, the analysis of the movement of the ingredient particles will make it possible to develop the structural and technological scheme of the crusher, which provides increased productivity by improving the conditions of the grain material separation process and timely unloading the finished product from the grinding chamber.
\end{abstract}

Key words: shredder, grinding, sieve, separator, grain.

\section{Introduction}

Hammer-type shredders have a variety of structural solutions aimed at organization of the technological process of feeding the material into the crushing chamber, grinding and removal of the crushed product. To date, domestic and foreign scientists, including V. G. Korotkov, A. V. Aleshkin, A. A. Sundeev, P. A. Savinykh, X. Zhao, H. Zhou, and S. Rong have formulated various analytical provisions in the field of development of ways to reduce the energy consumption and expand the functionality of hammer-type shredders of the closed type [1-5]. The aspect of the working process improvement is prevalent in the works of many authors on the theory of grinding.

The analysis and formalization of the process of the grain mass movement during its destruction were carried out partially, secondary. Both the efficiency of interaction with crushing elements and the productivity of extrication from the working chamber of conditioned material depended on the routing of flows [1;2]. From the operational point of view, in the technologies of bulk materials grinding by shredders, centrifugal segregation of the air product flow (hereinafter referred to as APF) was perceived by specialists as an exceptionally negative phenomenon [6-8]. The use of the nature of redistribution of heterogeneous particles in the working volume of the shredder was a prerequisite for creation of technologies that solve the problems of uneven grinding and high specific energy consumption [3;4].

The authors are proposing a technology for controlling the segregated APF inside the working chamber of the hammer-type shredder, based on the principle of timely separation from the total flow of conditioned particles and their removal to the side planes for removal from the working chamber. The technological effect is achieved by separating the moving flow of the milled grain material so that a large fraction consisting of "impassable" crushed and unbroken particles is fed to the hammers for further grinding, and the particles of the "pass" size are sent to unloading, Fig. 1 [9].

The purpose of the study is to identify the key structural and operational and technological parameters of organization of APF administration during the unloading condition of the grain mass from the crushing chamber of the grinding equipment. To achieve the goal it is necessary: to establish the laws of the kinematic interaction of particles of the milled material with the elements of the unloading system of the hammer mill through the side separating sieve; to develop a technique for optimizing the geometric parameters of the APF control system and unloading the finished product from the working chamber of the hammer-type shredder. 


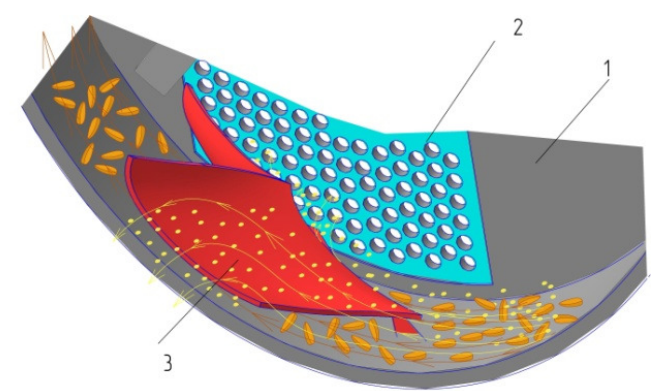

Fig. 1. Scheme of separator operation: 1 - housing; 2 - sieve; 3 - separator

\section{Materials and methods}

Integral indicators of the grain material separation process largely depend on the nature of the movement of individual ingredient particles relative to the plane of the separating sieve and the separator surface. Therefore, the trajectories and the velocity field of the crushed grain particles after their interaction with the separator surface until they touch the end surface of the working chamber (for the range of the separator installation angles in the range from $40^{\circ}$ to $50^{\circ}$ [10]) were studied. Particles moving in the conditioned layer deviated from the initial trajectory under the influence of the air-product flow. The interaction of the particle with the separator surface was considered as a perfectly elastic collision [3;11]. The methods of theoretical mechanics and of differential and integral calculus were used. In the transformed flow the particles moved with deceleration relative to the horizontal component of the flow and with acceleration relative to the circumferential component of the flow.
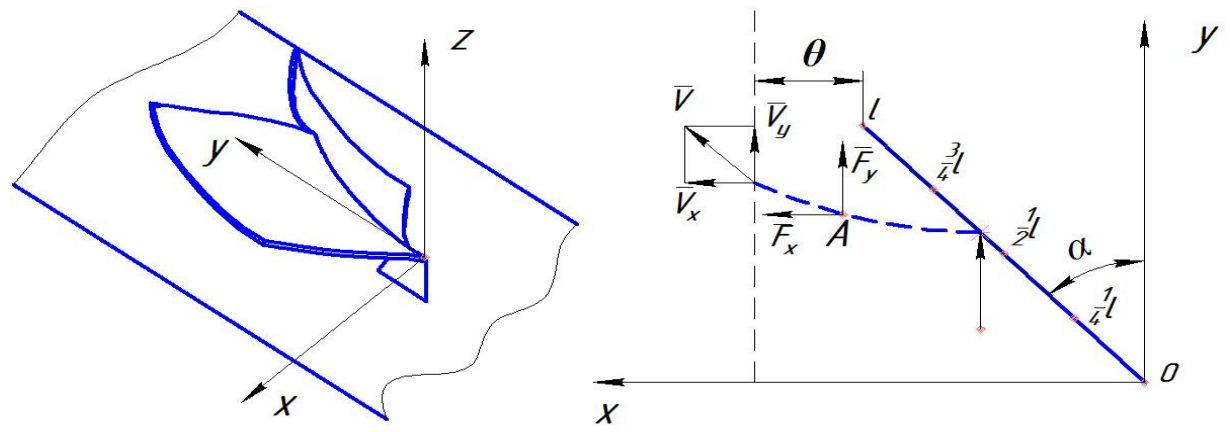

Fig. 2. Scheme of forces acting on particle after interaction with separator: $l$-reflector length, $\mathrm{m}$; $\theta$ - gap between the separator and the sieve, $\mathrm{m} ; A$ - grain particle

The separator is located at an angle $\alpha$ to the projection of the longitudinal axis of the working chamber on the horizontal plane. Taking into account the forces, Fig. 2, acting on the grain particle A, after reflection from the separator, the system of differential equations of motion in coordinate form has the following view

$$
\left\{\begin{array}{l}
m \frac{d V_{x}}{d t}=F_{x} \\
m \frac{d V_{y}}{d t}=F_{y} \\
m \frac{d V_{z}}{d t}=m g-\mu V_{z}^{2}
\end{array},\right.
$$

where: $m$ - mass of ingredient particles, $\mathrm{kg}$;

$F_{x}$ - force acting on the particle in the direction of the axis $\mathrm{OX}, \mathrm{N}$;

$F_{y}$ - force acting on the particle in the direction of the axis OY, N;

$g-$ acceleration of gravity $=9.81 \mathrm{~m} \cdot \mathrm{s}^{-2}$;

$\mu$ - coefficient of resistance of the medium, $\mathrm{kg} \cdot \mathrm{m}^{-1}$;

$V_{x}$ - speed of the particle in the direction of the $x$-axis, $\mathrm{m} \cdot \mathrm{s}^{-1}$; 
$V_{y}$ - particle velocity in the direction of the OY axis, $\mathrm{m} \cdot \mathrm{s}^{-1}$;

$V_{z}$ - particle velocity in the direction of the axis $\mathrm{OZ}, \mathrm{m} \cdot \mathrm{s}^{-1}$.

The force of gravity is insignificant in comparison with other forces, therefore, in further formalization the third equation can be neglected. Assuming the dependence of the resistance force on the quadratic velocity [3], we obtain

$$
\left\{\begin{array}{l}
\frac{d V_{x}}{d t}=-\frac{\mu}{m}\left(V_{x}-V_{H}\right)^{2} \\
m \frac{d V_{y}}{d t}=\frac{\mu}{m}\left(V_{\Delta}-V_{y}\right)^{2}
\end{array},\right.
$$

where $\frac{\mu}{m}=k_{p}$ - coefficient of proportionality, $\mathrm{m}^{-1}$;

$V_{H}$ - horizontal component of the air flow, $\mathrm{m} \cdot \mathrm{s}^{-1}$;

$V_{\Delta}$ - relative flow rate, $\mathrm{m} \cdot \mathrm{s}^{-1}$;

$V_{\text {per }}$ - circumferential speed, $\mathrm{m} \cdot \mathrm{s}^{-1}$.

The system of extraction of the conditioned particles through the side separating sieve suggests the possibility of changing the direction of the particle velocity vector in the carrier air flow. As a result, the resistance force of the medium changes, to overcome which part of the energy of the particle is spent. To assess the impact of the air environment on the character of the change of the speed and direction of travel of the ingredient particles, in the mode of implementation of the management of APF, the proportionality factor is applied $\frac{\mu}{m}=k_{p}[12]$.

The first equation of the system (2) is reduced to two variants:

$$
\begin{gathered}
\frac{d V_{x}}{d t}=k_{p}\left(V_{x}-V_{H}\right)^{2}, \\
\int \frac{V_{x} d V_{x}}{\left(V_{x}-V_{H}\right)^{2}}=-k_{p} \int d x .
\end{gathered}
$$

Integration of equation (4) in a variable and use of the Newton-Leibniz calculus (the limits of integration for the coordinate $x-[x ; l \sin (\alpha)+\theta]$, on the horizontal speed $\left[V_{p e r} \cos (90-2 \alpha) ; V_{x}\right]$ ) allows to obtain the dependence of the horizontal velocity from coordinates in an implicit form

$$
\ln \left|\frac{V_{x}-V_{H}}{V_{H} \cos (90-2 \alpha)-V_{p e r}}\right|-\frac{V_{H}}{V_{x}-V_{H}}+\frac{V_{H}}{V_{p e r} \cos (90-2 \alpha)-V_{H}}=-k_{p}(l \sin (\alpha \alpha+\theta-x) .
$$

Integrating the equation (3) according to time, taking into account the initial conditions, we obtain the dependence of time on the horizontal component of the grain particle velocity

$$
t=\frac{\frac{1}{V_{x}-V_{H}}-\frac{1}{V_{p e r} \sin (90-2 \alpha)-V_{H}}}{k_{p}} .
$$

Double integration of the second equation of the system (2) in time, taking into account the initial conditions $\left(t=0, V_{y}=V_{p e r} \sin (90-2 \alpha), y=0\right)$ allows to obtain the dependence of the velocity $V_{y}$ and coordinate $y$ on the time $t$

$$
V_{y}=V_{\Delta}-\frac{1}{k_{p} t+\frac{1}{V_{\Delta}-V_{p e r} \sin (90-2 \alpha)}},
$$




$$
y=V_{\Delta} t-\frac{1}{k_{p}} \ln \left(k_{p} t+\frac{1}{V_{\Delta}-V_{p e r} \sin (90-2 \alpha)}\right)+\frac{1}{k_{p}} \ln \left(\frac{1}{V_{\Delta}-V_{p e r} \sin (90-2 \alpha)}\right) .
$$

\section{Results and discussion}

Sharing of dependencies (5), (6), (7) and (8) allows us to obtain both trajectories of grain particles and their velocity field, Fig. 3, Fig. 4.

$$
\alpha=40^{\circ}
$$

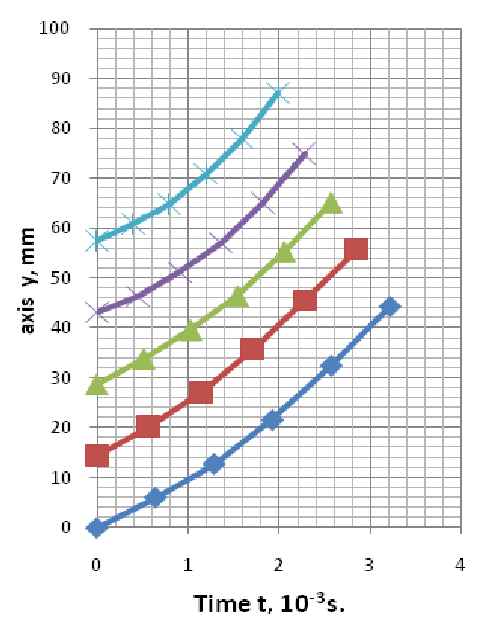

$\alpha=45^{\circ}$

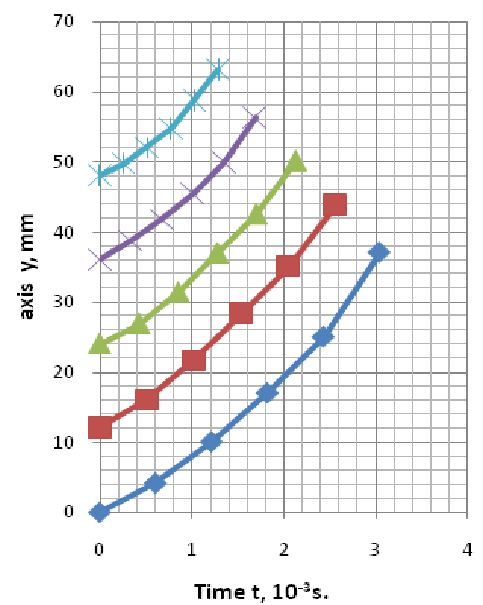

$\alpha=50^{\circ}$

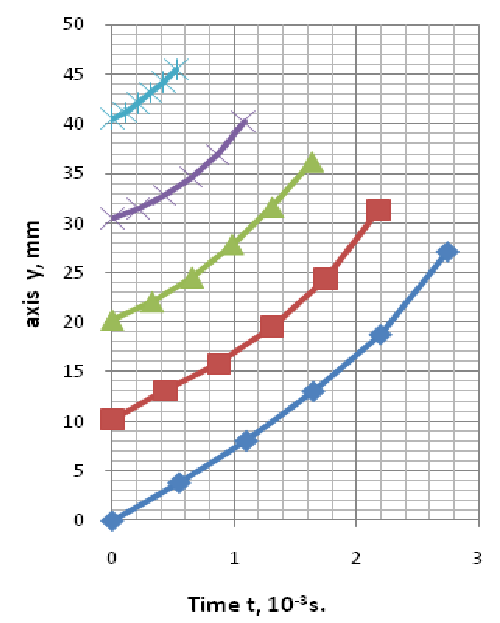

Fig. 3. Model visualization of particle motion in working chamber of shredder
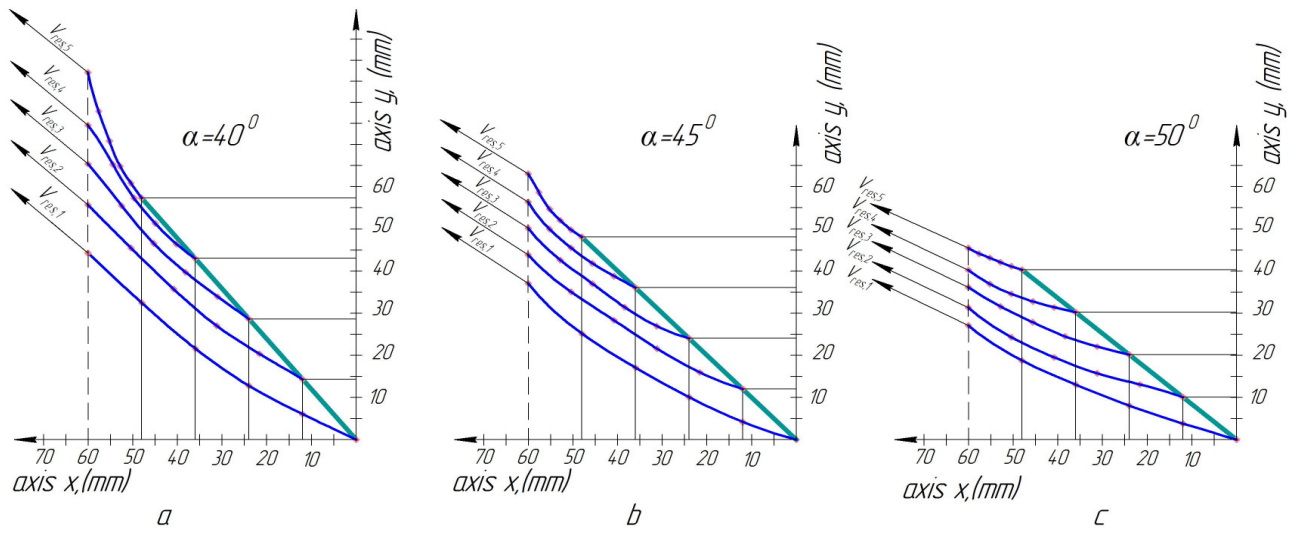

Fig. 4. Particle trajectories and direction of velocity vectors while contacting with hammer-type shredder sieve

The nature of transformation of the air flow indicates the possibility of regulating the operating mode, due to the variability of the angles of inclination of the generator of the separator to the longitudinal axis of the working chamber.

Within the range of the angles of generatrix inclination to the longitudinal axis of the working chamber (these boundaries were established empirically [10;11]) permissible perturbations of the air flow are observed, which allow steady implementation of the APF lateralization regime.

The boundaries of the discharge window zone are determined by a set of routes of individual particle motion reflected from the contact points on the generatrix, obtained by means of its conditional division into four equal segments. Five graphs were plotted for each angle in a separate coordinate system. The shifts of the graphs were determined by the coordinate $(y)$ of the contact point of the particle with the separator, Fig. 3.

The analysis of the particle motion trajectories shows that the length of the path traveled by the reflected particles to the boundary of the working chamber decreases with an increase in the angle of inclination of the working chamber to the longitudinal axis. There is a display of the effect of 
aerodynamic focusing of particles. The concentration of particles per unit discharge area in the direction of flow grows, Fig. 4, c. The functional scheme, which implements this physical model, suggests the possibility of abandoning the installation of the sieve plate. It also can be about a sieveless hammer-type shredder with high capacity due to the use of adequate conditions for discharge through the side of the plane of the working chamber. However, in this scheme, the probability of uneven dispersion of the resulting product is high [5;13]. At the same time, it should be noted that there is a possible prospect for further improvement of the proposed technological scheme, which allows obtaining high-quality feed with minimal energy consumption [2;4].

The separator with the angle of the generatrix inclination to the longitudinal axis of the chamber, tending to 40 degrees, requires the installation of a sieve with smaller dimensions. With the values of the angles with smaller values, there is a dispersion of particles along the length of the discharge zone and, as a consequence, the expansion of its boundaries.

The efficiency of the particle sifting process through the separating holes depends on the magnitude and direction of the velocity vectors relative to the sieve plate, from which the parts approach the hole. The duration of the processes of sifting essentially depends on this speed. The most favorable for sieving particles is the direction of motion of the material normal to the sieve cloth $[1 ; 2 ; 14]$.

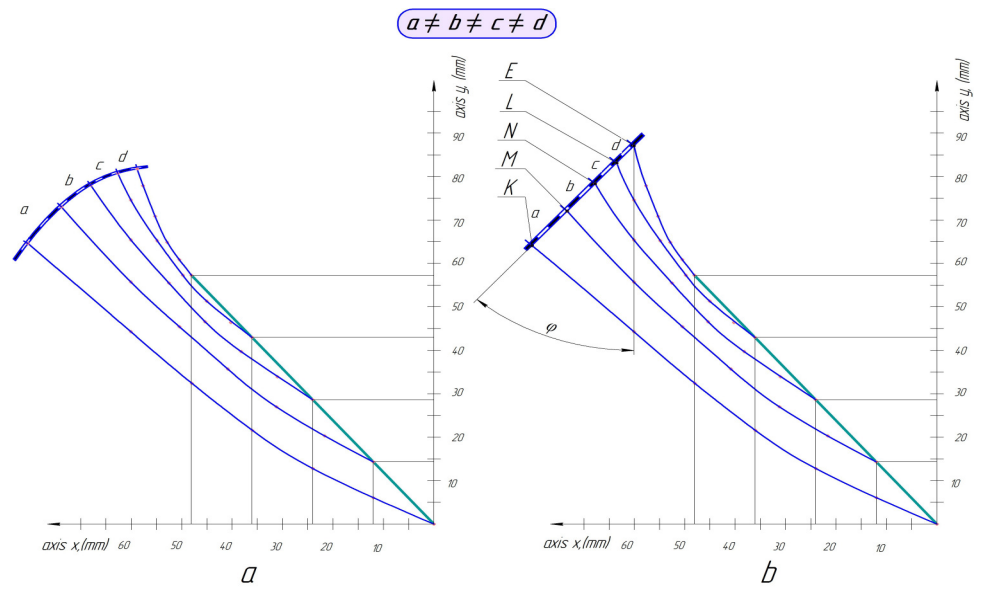

Fig. 5. View of trajectories with installation of sieve under angle $\varphi$

To fulfill the condition of effective sieving, it is necessary to use a curved sieve. Only in this case normal interaction of particles with the surface is ensured, Fig. 5, a. The sieve of the bent form is difficult in production and in operation. The theoretical analysis has revealed that for effective sieving it is possible to use a flat sieve set at an angle $(\varphi)$ and realizing the normal of the resulting velocity vector of the particles to the sieving plane, Fig. 5, b.

Both in the first and second versions of the lattice, Fig. 5, a, b, there is an uneven distribution of the discharged particles along the length of the discharge window $(a \neq b \neq c \neq d)$. As a result, the set of positive conditions for product separation through the sieve is reduced.

Full passage through the separating sieve of all fractional particles, the size of the smaller diameter of the holes will occur, if at least a single hit in any hole is possible. This is expressed by the condition of uniform unloading of the material immediately along the entire length of the unloading window $(a=b=c=d)$.

Leveling of the distribution of the particle density on the sieve is performed by changing the curvature of the generatrix of the separator. The variation of the curvature function in the overall limits of the working chamber allows to achieve uniform distribution of the points of contact $(\mathrm{K}, \mathrm{M}, \mathrm{N}, \mathrm{L}, \mathrm{E})$ along the length of the sieve, and the correction of the angle of reflection from the surface of the separator provides the offset of trajectories to the optimal parameters of the particle distribution, Fig. 6, a, b. 


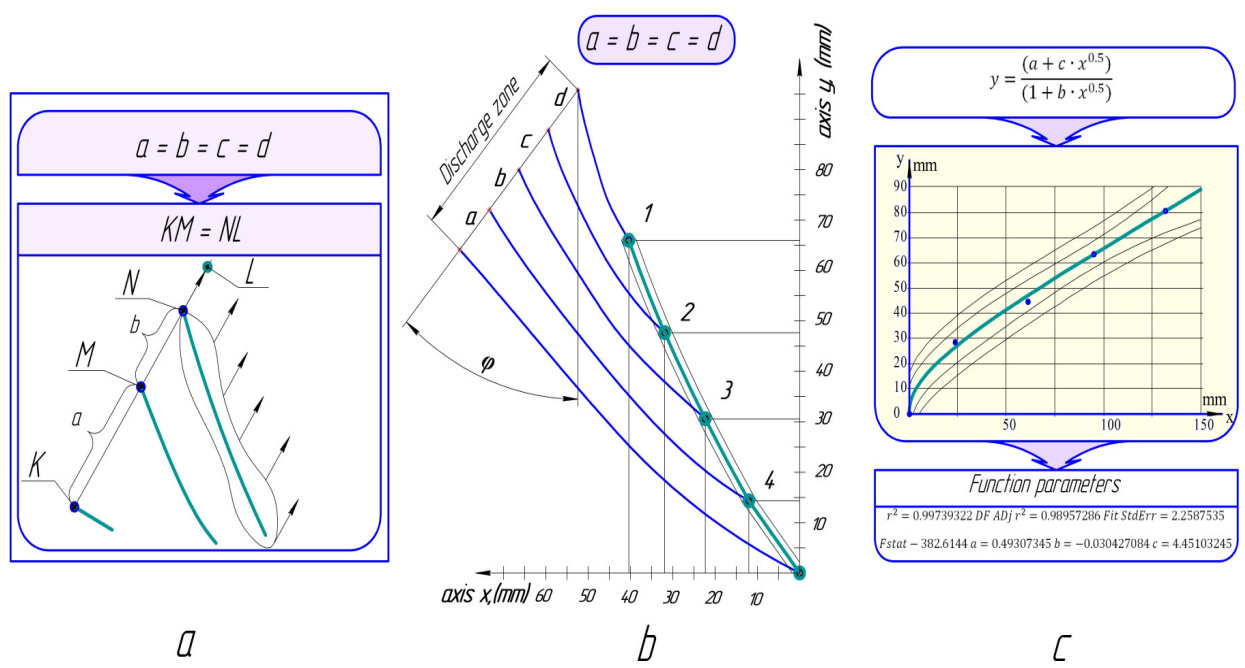

Fig. 6. Optimization of curvature of separator generatrix

Using the graph-analytical method for recovering the trajectories by the points coordinating uniform distribution of the product along the length of the sieve, Fig. 6, b, allows to obtain the shape of the separator surface.

The mathematical model, Fig. 6, c, for the shape of the separator surface implemented in the physical sample for the given arguments is received.

Thus, the concept proposed by the authors is not only to justify the methods of preventing the negative consequences of segregation, but also to improve the manufacturability as a result of its development.

The possibility of organized movement of fractional groups in the form of a segregated flow is confirmed by the results of theoretical and practical studies, on the basis of which an algorithm of design and engineering calculations of structural and operating parameters of the technical system for supplying the conditioned product to the zone of separating sieves is developed.

\section{Conclusions}

The method of theoretical study of the trajectory cycle correction of the comminuted raw material standard particles in the optimal area of the separating sieves is proposed. The possibility of justifying the permissible limits of the input parameters of the technical solution, taking into account the variability of the operating conditions and the simulated function, is presented. Functional dependences allow us to obtain the velocity field of the reflected conditioned particles in time and the trajectory of their motion in the lateralized air-product flow. At the angles of installation of the reflecting surface of the separator to the longitudinal plane of the working chamber in the range from 40 to 50 degrees it is possible to simulate the forms of the separator and sieve surfaces and their further coordinate orientation.

\section{References}

[1] Лебедев А.Т. Искендеров Р.Р., Очинский В.В., Павлюк П.А. Методологический подход к обоснованию принципа работы молотковой дробилки (Methodological approach to the justification of the principle of the hammer mill). Вестник Московского агроинженерного университета. (Bulletin of the Moscow Agroengineering University), №3 (67), 2015, pp. 24-28 (In Russian).

[2] Zhao X. Research on the New Combined Type Crusher Hammer. International Conference on Advanced Engineering Materials and Architecture Science, 2014, Vol. 488-489, pp. 1160 - 1164.

[3] Савиных П.А. Палицын А.В., Иванов И.И. Исследование измельчителя фуражного зерна роторно-центробежного типа с различными рабочими органами (Study of rotary centrifugal type fodder grain grinder with various working bodies). Молочнохозяйственный вестник (Molochno-khoziaistvenny bulletin), № 2 (26), 2017, pp. 119-129 (In Russian). 
[4] Сыроватка В.И. Обухов А.Д. Логическая структура методологии построения наукоемких предприятий по производству комбикормов (Logical structure of methodology of the knowledge-intensive enterprises construction on production of compound feeds). Вестник Всероссийского научно-исследовательского института механизации животноводства (Bulletin of the all-Russian research Institute of mechanization of animal husbandry), № 3, 2017, pp. 4-14 (In Russian).

[5] Sadri H., Ghorbani G.R., Alikhani M., Babaei M. und A. Nikkhah, 2007: Ground, dry-rolled and steam- processed barley grain for midlactation Holstein cows. Anim. Feed Sci. Technol. 138, pp.195-204.

[6] Иванова А. П. Межуева Л. В., Гунько В. В., Пискарева Т. И., Гетманова Н. В. Инженерная геометрия в проектировании смесителей (Engineering geometry in the design of mixers). Вестник Оренбургского государственного университета (Bulletin of the Orenburg State University), №10, 2010, pp. 138-140 (In Russian).

[7] Новиков В.В. Ермолаева Д.Р., Коновалов В.В. Обоснование направления совершенствования зоны загрузки устройства прессования материала (Substantiation of directions of improvement of the loading area of the device pressing of the material). Вестник Ульяновской государственной сельскохозяйственной академии (Bulletin of Ulyanovsk State Agricultural Academy), №3, 2016, pp. 179-184 (In Russian).

[8] Ferreira, Fernanda Altieri Passini, Roberta Borgatti, Laura Maria Oliveira de Souza, Rondon T.Y.B. Meyer, Paula Marques and Rodrigues, Paulo Henrique Mazza 2007. Effect of maize processing on diet selection in cows. Livestock Science, Vol. 112, Issue. 1-2, pp. 151-160.

[9] Шахов В.А. Ушаков Ю.А., Петров А.А., Абдюкаева А.Ф., Наумов Д.В. Анализ функциональной специфики дробильных устройств с боковым расположением выгрузных зон (Analysis of the functional specificity of the crushing device with lateral disposition of the unloading zones). Известия Оренбургского государственного аграрного университета (Izvestia Orenburg State Agrarian University), №4, 2018, pp. 181-184 (In Russian).

[10] Асманкин Е.М., Ушаков Ю.А., Абдюкаева А.Ф., Шахов В.А., Макаровская 3.В., Наумов Д.В. Кинематические и динамические аспекты взаимодействия ингредиентных частиц с функциональными элементами рабочей камеры измельчителя зернового материала (Kinematic and dynamic aspects of interaction ingredient-tion of particles with the functional elements of the working chamber of a grinder of the grain material). Известия Оренбургского государственного аграрного университета (Izvestia Orenburg State Agrarian University), №3, 2017, pp. 87-89 (In Russian).

[11]Булатов С.Ю. Нечаев В.Н., Миронов К.Е. Исследование взаимодействия зерна с лопастями ротора дробилки закрытого типа (Study of interaction of grain with rotor blades of crusher of closed type). Вестник НГИЭИ (Bulletin NGIEI), № 8, 2017, pp. 26-34 (In Russian).

[12] Шахов В.А. Ушаков Ю.А., Асманкин Е.М., Наумов Д.В. Методика оценки взаимодействия ингредиентных частиц зерновой массы и воздушного потока в рабочей камере дробильных машин (Methods of assessing the interaction of the ingredient particles of the grain mass and the air flow in the working chamber of crushing machines). Научно-технический прогресс в сельскохозяйственном производстве: материалы международной научно-практической конференции, посвященной 110-летию со дня рождения академика М.Е. Мацепуро (Scientific-technical progress in agricultural production: materials of international scientificpractical conference dedicated to the 110th anniversary from the birthday of academician M.E. Matsepuro / ed. by P. Kazakevich) - Minsk: SPC NAS of Belarus for mechanization of agriculture, 2018, pp. 196-200 (In Russian).

[13] Dehghan-Banadaky M., R. Corbett und M. Oba, 2007: Effects of barley grain processing on productivity of cattle. Anim. Feed Sci.Technol. 137, pp. 1-24.

[14] Искендеров Р.Р. Лебедев А.Т. Молотковые дробилки: достоинства и недостатки (Hammertype shredders: advantages and disadvantages). Вестник АПК Ставрополья (Bulletin APK Stavropol), №1 (17), 2015.pp. 27-30 (In Russian). 